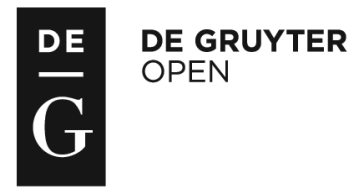

Administration, vol. 65, no. 2 (2017), pp. 145-164

doi: 10.1515/admin-2017-0019

\title{
Reforming the Irish public service: A multiple streams perspective
}

\author{
Muiris MacCarthaigh \\ Queen's University Belfast
}

\begin{abstract}
Following the Irish general election of 2011, a new ministry emerged which sought to combine public expenditure, industrial relations and public sector reform. The creation of the Department of Public Expenditure and Reform (DPER) represented a major departure in Irish administrative history, not least because it introduced a new actor at the heart of Irish government, but also for the range of tasks with which it was endowed. This article provides an administrative reform context for the creation of DPER before examining its work across three domains: industrial relations, financial management reform and administrative reform. Drawing on Kingdon's 'multiple streams' model of policy change, the article argues that reform efforts across all three were made possible by the 'window of opportunity' presented by the department's creation and the coming together of problems, policies and politics in respect of public service reform.
\end{abstract}

Keywords: Ireland, public administration, global financial crisis, public service reform, multiple streams

\section{Introduction}

A decade has passed since the onset of the global financial crisis, yet many governments across Europe still struggle to stabilise their budgets, reduce public debt and grow their economies. There has been 
considerable diversity in how governments have responded to the crisis (see Bideleux, 2011; Kickert, 2012; Peters et al., 2011), with many (including Ireland) requiring external interventions. However, programmes of administrative reform and cutback management have been common responses and remain important elements of retrenchment strategies likely to continue for some time (Coen \& Roberts, 2012; Lodge \& Hood, 2012; Peters, 2011; Pollitt, 2010; Thynne, 2011). How these bureaucratic reform measures have been managed and institutionalised has varied according to administrative tradition, the scale of the crisis and political circumstance (Hardiman \& MacCarthaigh, 2016).

The use of departmental ministries is a particularly prominent method of demonstrating political commitment to a policy field or problem. In the context of the Irish general election of 2011, in which promises of substantial political and administrative reform formed part of the manifestos of all major parties, a new ministry emerged which sought to combine public expenditure, industrial relations and public sector reform. The creation of the Department of Public Expenditure and Reform (DPER) represented a major departure in Irish administrative history, not least because it introduced a major new actor at the heart of Irish government, but also for the range of tasks with which it was endowed. This article begins by providing an administrative reform context for the creation of DPER before examining its work across three domains: industrial relations, financial management reform and administrative reform. Following this, and drawing on Kingdon's (1995) 'multiple streams' model of policy change, the paper argues that reform efforts across all three were made possible by the 'window of opportunity' presented by the department's creation and the coming together of problems, policies and politics in respect of public service reform.

\section{A multiple streams approach to policy change}

Many approaches exist for conceptualising policy change in government (Cairney, 2012; John, 2012). One such approach is the 'multiple streams' model proposed by John Kingdon (1995) in his seminal work on policy agendas in the US. In this book, he argued that policy did not develop in a linear process involving problem identification, development of options and then a choice made by a political principal. Rather, he proposed a 'multiple streams' framework, suggesting that change only occurred within the 'policy primeval 
soup' (1995, p. 117) when there was a confluence of streams: problem streams, policy streams and political streams. When these streams were aligned, it presented a 'window of opportunity' for reform that might otherwise not be possible. Timing is therefore important for the multiple streams approach, as is the emphasis on the ability of nonelites to influence policy.

Windows of opportunity do not have agency; rather, they are exploited by what Kingdon calls 'policy entrepreneurs'. Such entrepreneurs have the capacity, knowledge and incentive to use the window to advance their own policy goals. Examples might include bureaucrats and political elites, but also organised civil society groups or other actors in positions of authority. In all cases, these entrepreneurs are aware of the potential for change offered by the window of opportunity, and have the resources to exploit it independently or through collaboration. Building on this work, Herweg et al. (2015) particularly emphasise the policy role played by political parties in creating and exploiting these windows of opportunity.

Although it has clear limitations in terms of hypothesis-testing, in respect of public service reform, a multiple streams approach is particularly useful for conceptual understanding of why significant reform efforts occur occasionally rather than continuously, and why some reforms are chosen over others. Indeed, as Zahariadis (2016) identifies, the popularity of a multiple streams approach is due to its role in explaining change under conditions of ambiguity. In the case of Ireland, the series of crises beginning in 2008 led to considerable policy ambiguity and uncertainty, which were used to good effect by those adopting the 'never waste a crisis' mantra upon coming to power following a general election in 2011. Before examining the incidence and content of these reforms, the context of the administrative reforms prior to 2011 must be presented.

\section{Administrative reform prior to 2011}

From late 2008 until 2014, two successive Irish governments engaged in a series of austerity budgets in which public spending contracted rapidly. These budgets were necessitated by the combined banking, financial and economic crises which began in 2008 (Donovan \& Murphy, 2013; Whelan, 2014). Amongst other issues, a number of official reports commissioned in the aftermath of the crises pointed to a lack of timely critical debate and analysis by bank analysts and the 
public at large, aligned with a sense of complacency within government and other authorities (Regling \& Watson, 2010; Nyberg, 2011). A report into the role of the powerful Department of Finance made particular reference to the issue of public service reform:

Some significant strides have been made in the area of Public Service Modernisation, particularly on improved electronic and other services to the public. However progress on Public Service Modernisation generally has been very disappointing. The Department of Finance must bear its share of the responsibility for this. The Department has not prioritised Public Service Modernisation, and has devoted limited resources to the area. (Wright, 2010, p. 38)

Public service reform had been a vexed issue for years, with responsibility divided between the two key ministries at the heart of Irish government - the Department of Finance and the Department of the Taoiseach (Prime Minister). With administrative reform remaining largely outside of ideological or partisan politics, Ireland was considered a laggard in respect of the managerial reform trends that occurred in other Westminster-Whitehall bureaucracies during the 1980s and 1990s (Hardiman \& MacCarthaigh, 2011). In fact, on the eve of the crisis, the Irish government was handed the final report of a study it had commissioned the OECD to undertake, which sought widespread reform of the public service. Titled Ireland: Towards an Integrated Public Service, the OECD described a bureaucracy beset by institutional fragmentation, weak coordination and poor performance-management practices. It suggested that since the early 1990s, 'Ireland has significantly advanced along a "New Public Management" continuum' (OECD, 2008, p. 18), without detailing what this continuum comprised. It presented a list of reform ideas which majored on better coordination and a performance-based culture, but which in the face of the financial crisis disappeared from the agenda as economic stability took precedence. However, many of the reform ideas within the OECD's report, including those around shared services and performance budgeting, were to re-emerge within a number of years.

As the budgetary situation deteriorated in 2008, talk of reform gave way to 'efficiency' cuts in public services, including public pay. A moratorium on public service recruitment, which had been put in place in 2007, was extended. And in the aftermath of a controversial 
blanket banking guarantee in September 2008 (Whelan, 2014), an early 'emergency' budget for 2009 was published in October 2008, which prohibited any increases in public spending. A Special Group on Public Service Numbers and Expenditure Programmes, led by prominent economist Colm McCarthy, conducted a 'stocktaking' exercise, which identified $€ 5.3$ billion in savings and recommended a reduction in public service personnel of about 5 per cent. Considered drastic at the time, later cuts of over $€ 20$ billion and a reduction in public service numbers of almost 10 per cent would result.

The Irish economy continued to deteriorate during 2009, and the budget for 2010 introduced another, slightly less severe round of expenditure cuts, including pay reductions (on a tiered basis) and changes to pension entitlements for public servants. As a result of these measures, as well as incentivised schemes for early retirement and career breaks, the gross rates of public service pay were reduced by about 14 per cent cumulatively over 2009 and 2010. It was still insufficient to stabilise the public finances, however, and the government was eventually forced to agree a loan package with the 'troika' of the International Monetary Fund, the European Central Bank and the European Commission in December 2010. The troika package was dependent on a programme of economic reforms which the government would undertake under the terms of the loan, and was titled the National Recovery Plan 2011-2014 (Government of Ireland, 2010). And though the agreement was silent on the detail of public service reform measures, the troika accepted proposals for reform of the Irish budgetary and financial management framework, including stronger links between expenditure and performance measurement. Achieving the targets set by the troika was also linked to reform efforts that emphasised the need for efficiencies in public spending.

\section{The creation of DPER}

Within weeks of signing the loan programme memorandum with the troika, the coalition government that had been elected in 2007, and that had weathered over two years of ad hoc cuts and reform measures, disintegrated and an election was called for February 2011. The issues of political and administrative reform formed an important part of the election campaign, with all major parties presenting lists of proposed reform measures in their manifestos to the electorate. The election result delivered a combined total of 113 , or 68 per cent of, seats in the lower house for a coalition of centre-right Fine Gael and 
centre-left Labour Party, and thus a significant mandate for reform. The programme for government subsequently adopted by the new administration set out an ambitious agenda of 'whole of government' reforms, ranging from abolishing the upper house of parliament and the secondary tier of Irish local government (town and borough councils) to new public service data-sharing and public procurement regimes (Government of Ireland, 2011). To manage these reforms, the new government made an important institutional innovation, which was to create a new ministry - DPER - and, in so doing, to break up the traditional duopoly at the heart of Irish government between the Department of Finance and the Department of the Taoiseach.

The new department took functions from both, though principally the public expenditure sections from the Department of Finance, and combined in one organisation the issues of public sector reform, industrial relations and expenditure management. As well as reducing the power of the Department of Finance, the decision to create the new department also solved a political problem by allowing for the smaller coalition partner to have two major cabinet positions, and to have co-equal status at the Economic Management Council (see below). The process of developing the legislation to give the new department authority was an enormous one, involving a trawl of all primary and secondary legislation since the foundation of the state relating to the functions of the Minister for Finance and distributing the functions between DPER and Finance. The latter department was left to focus on budgetary and macroeconomic issues, including taxation, as well as reform of the damaged banking sector. Apart from its unique combination of roles, DPER was distinctive in the composition of its management board, which brought together a cohort of senior managers from outside as well as within the public service, and in its use of non-conventional (for the civil service) managerial titles such as chief operations officer, chief information officer and various director roles. And in a break from pre-crisis practice, senior officials with considerable private sector experience were recruited to manage large reform projects in such areas as shared services and procurement (MacCarthaigh, 2014b).

With the crisis providing a 'window of opportunity', DPER provided the necessary institutional means for a number of policy entrepreneurs to address new but also long-standing policy problems related to public service reform. The Minister for Public Expenditure and Reform, Brendan Howlin, TD, had long-standing interests around aspects of political and administrative reform, and was able to pursue 
these not just through his department but also with the support of key political fora (see below). The new senior cadre of officials in his department were also presented with the means (primarily expenditure controls, but also a strong political mandate) to address policy problems around administrative reform that had evaded previous administrations.

As well as assuming responsibility for the annual financial and budgetary process, DPER therefore developed two whole-ofgovernment public service reform plans which encapsulated the policy solutions it wished to implement (Department of Public Expenditure and Reform, 2011, 2014). In terms of ensuring that the reform plans were implemented beyond central government, a new oversight and reporting structure was created. At the apex, a cabinet sub-committee on public sector reform was created, chaired by the Taoiseach, which provided a key mechanism for overcoming any internal bureaucratic barriers to reform. It also served to firmly link administrative reform with the national economic recovery effort.

DPER was also represented in a new powerful decision-making forum within the cabinet, known as the Economic Management Council (EMC). The EMC consisted of the Taoiseach, the Tánaiste, and the Ministers for Finance and Public Expenditure and Reform, as well as their top officials and economic advisers. The EMC's role was to manage reforms related to the troika loan programme, and to provide for faster executive decision-making. The EMC's approval of DPER's public service reform agenda as part of the national response to the economic crisis gave it further political authority for implementation.

\section{Industrial relations}

Prior to the crisis, public sector pay and reform was negotiated through triennial 'social partnership' agreements between government, trade unions, business and farming interests (and later a social or 'community and voluntary sector' pillar) that had been a feature of public policymaking since 1987. In the context of the economic crisis, the multi-actor social partnership process fell apart, and instead the government negotiated directly with public service unions alone. 1 Following negotiations, a new deal titled the Public Service Agreement 2010-2014 was agreed at the end of March 2010.

${ }^{1}$ In fact, as the crisis took hold in September 2008, the government hurriedly signed a new pay deal with unions, the terms of which it was quickly unable to honour. 
Popularly known as the Croke Park Agreement, the key provisions were:

- no further public service pay cuts until at least 2014;

- significant cost-saving reform measures to be implemented across the public service;

- a review in spring 2011 of the extent of savings generated to determine any scope for the reversal of pay cuts;

- a reduction in public service staff numbers;

- no compulsory redundancies but flexible redeployment arrangements to be introduced;

- creation of a unified public service labour market;

- promotion and incremental progression to be based on performance;

- an industrial peace clause to be put in place.

The agreement, and the associated detailed monitoring programme, provided a vital platform for introducing changes to work practices at the local organisational level that had previously proved resistant to reform plans under social partnership agreements. Significantly, it contained proposals that had featured in pre-crisis reform initiatives (particularly around performance and mobility) but that had not been achieved through the social partnership process. In the context of potential job losses and further pay cuts, public servants agreed to engage in these reforms (including longer working hours, reductions to leave and cancellation of pay increases) over the period of the agreement. The new government which came to power in early 2011 initially agreed to honour its terms. However, by the end of 2012 it became increasingly clear that the pay bill was still too large to achieve the targets set by the troika. DPER engaged with other departments to identify agreed positions for negotiations with public service unions, undertook necessary preparations and represented the government in negotiations. Thus, it presented a singular voice for dealing with all licensed unions across the public service.

Formal negotiations between the government and unions took place in January 2013 on a new pay deal. Although the draft of an early deal was rejected by unions, agreement was eventually reached on the Public Service Stability Agreement 2013-2016 (popularly known as the Haddington Road Agreement), which was signed by both parties in May 2013 and superseded the Croke Park Agreement. As part of the new agreement, a final round of graduated cuts (ranging from 5.5 to 
10 per cent) to those on higher salaries (over $€ 65,000$ ) were made in order to secure savings of a further $€ 1$ billion by 2015. In contrast with the Croke Park Agreement, which had envisaged a global savings target, the Haddington Road Agreement had a more defined set of reform measures, each with associated target savings. In effect, DPER had been able to use consultation under conditions of economic duress to achieve specific reforms that negotiations had conspicuously failed to achieve in the past (Hardiman \& MacCarthaigh, 2011).

By late 2014, and in the context of improving economic conditions, unions began to seek a reversal of the deep cuts to pay and pensions that had occurred since 2008. In expectation of a pay claim in early 2015 from the unions, DPER began looking at a strategy for a new round of pay negotiations, including consideration of what pay increases could be facilitated when the terms of the Haddington Road Agreement ended in mid 2016. The department was keen that reforms which enabled containment of payroll costs across the system be secured, and that there would be no reversal of the productivity changes in place arising from the Croke Park and Haddington Road deals. Unlike the Croke Park and Haddington Road Agreements, which had been negotiated over months, there was a desire on the part of both DPER and the unions to have a very short negotiation period. In the event, what became known as the 'Lansdowne Road Agreement' took just three weeks to negotiate, and a final deal was agreed in May 2015. Formally titled the Public Service Stability Agreement 2013-2018, it extended the Haddington Road Agreement by two years and began the process of 'unwinding' the legislative provisions that had been used to implement cuts to pay and pensions since 2008. By the end of the government's term, industrial peace had been largely maintained in the public sector during a period of extraordinary challenge. As the economy improved through 2016, however, pressure for speedier unwinding of cuts led to a new government, elected in May, agreeing to the establishment of an independent Commission on Public Sector Pay, taking the task out of DPER's hands. DPER was content to divest itself of this role and to depoliticise the issue as much as possible.

As Figure 1 identifies, the period after 2008 witnessed a contraction in public service numbers of approximately 10 per cent, surpassing a 2014 target set by the troika in 2010. While the effects were successful in reducing the pay bill (without industrial action), by 2015 it had created an unusual demographic profile for the public service, with few staff under thirty years of age or over sixty. The nature of 
recruitment also began to change, with all senior public service positions open to external recruitment, a position that had been resisted by unions prior to the crisis. Furthermore, when general recruitment restarted in 2015, it was for more position-based and skilled appointments rather than for a continuation of the generalist character that had existed prior to the crisis.

Figure 1: Irish public service numbers by sector 2006-14 (including 2014 target agreed with troika in 2010)

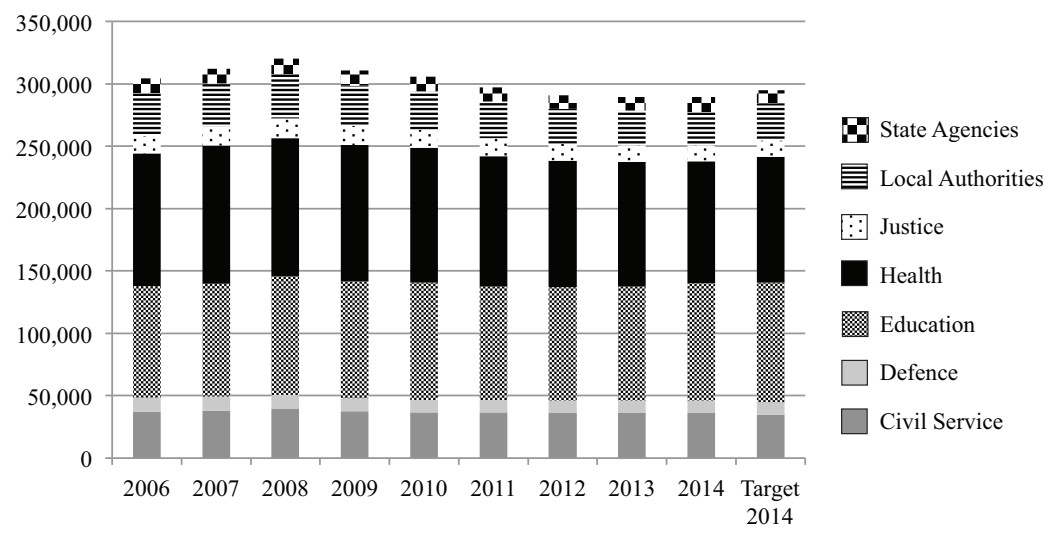

Source: DPER Databank (http://databank.per.gov.ie), Government of Ireland (2010, p. 64).

\section{Financial management reform}

Combined, the Croke Park, Haddington Road and Lansdowne Road Agreements were essential in the implementation of major reform efforts, particularly those concerning financial management reforms. The scale of the Irish financial and economic crisis resulted in considerable criticism of the state's budgetary and financial management processes. There were two interrelated frameworks for their reform. Firstly, Irish budgetary reforms were heavily influenced by changes initiated at the European level, including the stronger 'preventive' and 'corrective' dimensions of budgetary policy for member states. Secondly, budgetary reforms were shaped by the threeyear loan programme memorandum agreed with the troika, which committed the state to a number of initiatives in respect of budgetary and financial management. 
In line with other EU states, from 2013, budget day was moved forward from December to mid October. The Irish government was also obliged to produce a Stability Programme Update, identifying aggregate fiscal plans and related macroeconomic projections for the forthcoming budget year and into the medium term. The government passed the Fiscal Responsibility Act, 2012, to provide for its EU obligations under the Fiscal Compact, which was adopted in 2012. A centrepiece of the act was to legislate for the Irish Fiscal Advisory Council (IFAC), which had been created on a provisional basis in July 2011. The legislation assigned IFAC the power to assess and monitor the forecasts of the Department of Finance, compliance with European budgetary rules and the general appropriateness of the government's fiscal stance. It is also mandated to comment publicly on whether the government is meeting its budgetary targets and objectives.

Arising from the troika agreement, in March 2011 the Department of Finance published Reforming Ireland's Budgetary Framework: A Discussion Document (Department of Finance, 2011). Demonstrating their policy entrepreneurship, the reforms to the Irish public financial management process were in fact those proposed by Irish officials in 2010 (who had developed them in response to the crisis) and subsequently accepted by the troika. The proposed new budgetary architecture involved considerable institutional reforms to the Irish annual budgetary process, with a view to restoring Ireland's international credibility as well as better domestic fiscal governance and budgetary outcomes. There were two major changes to the new budgetary regime. The first was the introduction of multi-annual expenditure ceilings. This was an attempt to switch from short-term (annual) to medium-term (three-year) considerations of spending at budget time. Once published, it was expected that subsequent annual expenditure plans would respect these predefined ceilings for that year. However, this change was formalised by administrative circular rather than by legal statute - a shortcoming noted by the European Commission in its country peer review of fiscal governance (European Commission, 2013, p. 43).

The second was the creation of a new performance reporting regime. Under the Ministers and Secretaries (Amendment) Act, 2013, all government departments were required to produce performance statements, with a view to better alignment of decisions on spending with policy outcomes. It also served the objective of providing parliamentarians and the public with a clearer indication of how 
resources were being used. A series of policy results and performance indicators were also developed for policy actions so that previously separate documents for outputs, financial allocations and performance information were more closely integrated. Three-year trend information was also presented and a new public web-based database called Ireland Stat (www.irelandstat.gov.ie) was created, which provides information about government progress in achieving policy goals.

In parallel with these changes, DPER undertook two 'root-andbranch' Comprehensive Reviews of Expenditure, in 2011 and 2014. Both involved a detailed analysis and assessment of all programmes of expenditure, with all government departments required to identify options for savings for the first review in 2011. The first review resulted in the publication of the Comprehensive Expenditure Report 2012-14 alongside the coalition's first budget, and a 'whole-of-year' approach to budget development in line with EU requirements. Consistent with the reformed public spending code, the second Comprehensive Expenditure Report set out the multi-annual expenditure ceilings for all 'votes' for each of the years of 2015-17 inclusive.

Finally, an important development in the government's financial and budget management reform was the creation of a new economic service. The Irish Government Economic and Evaluation Service (IGEES), housed in DPER, recruited graduate economists and, in early 2014, began to publish its economic evaluations, exposing policy development in a manner that was previously unusual for Irish government.

Bringing together public spending, industrial relations and public sector reform for the first time in a single ministry provided the necessary levers to ensure that financial and administrative reforms would be linked to expenditure allocations (and pay) across the public sector. However, in terms of budget-making, the decoupling of revenue-raising and expenditure between departments may be considered a concentration, rather than a diffusion, of authority. The transfer of controls over spending to DPER led to greater responsibility among fewer officials in that department, and thus a centralisation of budgetary management, which is a common response to crisis (Levine, 1979). However, the implementation of cuts was operated in a decentralised manner, with departments given targets to achieve not just in terms of personnel but also in terms of their financial envelope for the year ahead. 


\section{Administrative reform}

As noted above, DPER published two public service reform plans during the 2011-16 period. The 2011 public service reform plan contained fourteen key reform targets designed to deliver substantial cost savings to the state, including:

- reducing the public service pay bill by 15 per cent by 2015 (based on 2008 figures);

- reducing public service staff numbers by 37,500 to 282,500 by 2015 (from a peak of 320,000 in 2008);

- reducing the number of state agencies;

- standardising annual leave across the public service;

- improving data-sharing across the public service;

- reforming procurement;

- greater sharing of HR, payroll and pensions services across the civil service;

- the potential for a 'GovStat' online initiative to be evaluated, to provide more information about public service performance;

- greater use of performance management, for both organisations and individuals.

As with the pay agreements signed with unions and the troika programme, a number of the administrative reform proposals in DPER's public service reform plan had previously been voiced but with little success. In particular, the recommendations of the pre-crisis OECD review, and the subsequent Transforming Public Services (Department of the Taoiseach, 2008) report, were influential and were reintroduced (by means of the new plan) by senior officials in the Department. In early 2012 the government approved a mandate for a Reform and Delivery Office to create new structures across the main sectors of the public service to implement the plan, which would report to the cabinet sub-committee on public sector reform. These included an Advisory Group of Secretaries General, chaired by the Secretary General of DPER, and a Reform Board, involving a senior official from each of the other fifteen government departments. A 'senior responsible officer' was also identified, with responsibility to ensure implementation of reform projects in the large spending sectors (including Health, Education, Social Welfare). This level of oversight had been missing from previous (pre-crisis) reform efforts, resulting in reforms not being well coordinated or monitored. A number of major 
national administrative reform initiatives also took shape with DPER, including the creation of a National Shared Service Office and the Office of Government Procurement. In both cases, major cost savings were sought through the amalgamation of functions common to many public service organisations into single entities.

An important innovation that took shape during the latter half of the government's period in office was a project to renew a focus on shared public service values and culture in a bottom-up manner. This was developed through a series of innovative 'town hall' meetings of civil servants across the state. In parallel, a study on the relationship between ministers and top civil servants was conducted, with a view to addressing long-standing concerns about the distribution of accountability between political and administrative realms. These two strands of work were integrated into a single report known as the Civil Service Renewal Plan, which recommended change through twenty-five actions across four themes:

i. a unified civil service, with the civil service operating more often as a single organisation;

ii. a more professional service, with a greater emphasis on enhanced performance of employees and organisations;

iii. a more responsive service, through changes in culture, structure and process;

iv. a more open and accountable service, receptive to external ideas and challenge.

Perhaps the most important feature of the plan, however, was that it was signed by all secretaries general and launched at a high-profile event in 2014 by the Taoiseach and Minister for Public Expenditure and Reform, with all signatories present. Within DPER, a Renewal Programme Development Office was created, with staff from other departments coming to work in the office on secondment to help embed the process in their department.

In order to progress the plan's actions, a number of new nonstatutory fora were created:

- A Civil Service Accountability Board, chaired by the Taoiseach, which would have oversight of the implementation of crosscutting priorities set by the government, and the capacity and capability of the civil service. This latter role included the introduction of a performance management system for secretaries general. 
- The creation of a Civil Service Management Board to manage the performance and operation of the civil service, support the government on the implementation of cross-departmental policy initiatives, identify and manage strategic and operational risks, and lead implementation of the Civil Service Renewal Plan.

These accountability and management boards were also designed to subject top civil servants to regular performance reviews, and to tackle cross-government policy problems that had previously fallen foul of departmental boundaries and accountability systems. The management board in particular has played an important role in ensuring a number of cross-departmental projects are being pursued by groups of secretaries general in a manner that had previously eluded Irish governments. Departmental capacity and capability reviews (which had emerged prior to the crisis but were quickly wound up) were reintroduced, which were to be published along with updates on the implementation of recommended reforms. The plan also recommended the development of a unified learning and development strategy based on an assessment of future skills requirements in both specialist and generalist areas.

Another high-profile element of the administrative reform agenda under DPER was a 'rationalisation' of the Irish administrative system's organisational profile. As Figure 2 identifies, the post-2008 period witnessed the first year-on-year reduction in the number of public organisations in the history of the state. Initial ambitions for large 'culls' or agency terminations turned out to be problematic in practice (MacCarthaigh, 2014a), and achieved modest budgetary savings, but a series of other reforms resulted in the nature of department-agency relationships undergoing an important process of change. Indeed, Dommet et al. (2016) find that agency governance in Ireland now exhibits far greater levels of regulation than before the crisis, including a shift away from periodic to more sustained engagement in agency-department relationships. DPER was centrally involved in these changes, including an emphasis on critical reviews of each agency's mandate, performance-based agreements between agencies and parent departments, and the need for more robust business cases for the creation of agencies than previously existed.

Local authorities also experienced considerable rationalisation, with associated budgetary cuts being very large compared to other sectors of the bureaucracy, and a host of small sub-national agencies being amalgamated or closed and their functions absorbed into local 
Figure 2: Number of public organisations in Ireland (other than ministerial departments), 1922-2014

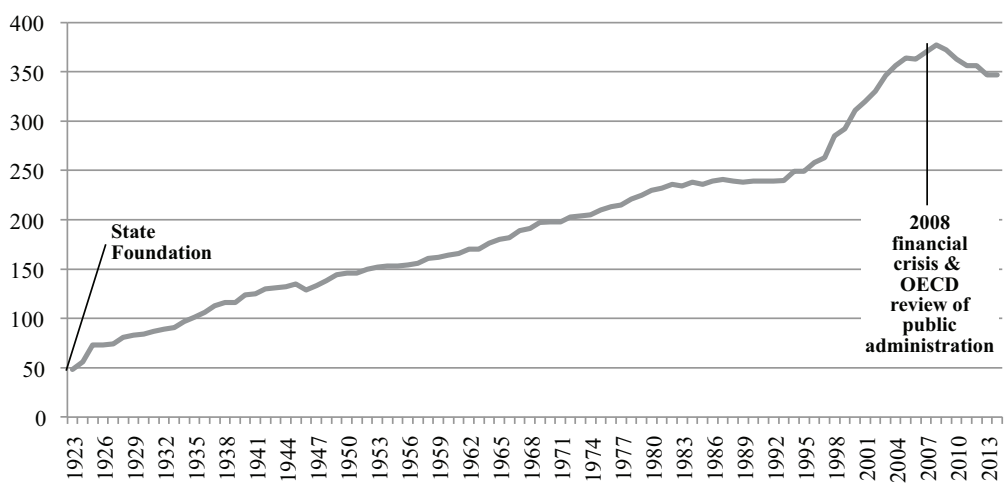

Source: Hardiman et al. (2014).

authorities. The network of 80 small municipal town and borough councils ceased to exist after 2014. By 2015, the 114 elected subnational authorities that existed prior to the crisis had been reduced in number to just 31. A review by Shannon found that of the 236 nonelected local and regional bodies in existence in 2012, only 96 (or 41 per cent) were in place 4 years later (Shannon, 2016, p. 18).

DPER advanced modernisation and reform initiatives across a range of other policy domains. These included the Irish public service's progress in relation to open data and data-sharing between public bodies. Ireland joined the international Open Government Partnership as part of this, and an Open Government Action Plan was published in 2014. The development of professional pathways for economists and HR specialists was also started within the department, as well as more publicly accessible information on the performance of government from Ireland Stat (see Downes et al., 2013). Legislation to regulate protected disclosures (or 'whistle-blowing') and lobbying was promulgated alongside extensions to the scope of the Office of the Ombudsman and the freedom of information regime.

The views of public servants on the effects of these reforms are revealing. A survey of senior Irish public executives published in 2014 found that 62 per cent felt the administrative system had improved over the 2008-13 period, but the remaining 38 per cent felt that it had deteriorated (Boyle, 2014, p. 35). When compared with other European states, Irish respondents tended to be more positive in their 
assessment of how the public service had performed over the previous five years, particularly in respect of policy effectiveness, policy coherence and coordination, cost and efficiency, external transparency, and openness and ethical behaviour. However, the results also found that Irish public service managers reported a stronger deterioration with regard to citizen trust in government, the attractiveness of the public sector as an employer and staff motivation when compared with other states (Boyle, 2014, pp. 35-6).

\section{Conclusions}

The creation of DPER was a vital part of the Irish response to the economic crisis and, alongside the creation of the EMC, was a major institutional innovation of the Fine Gael/Labour Party coalition government. The department also provided a focus for policy entrepreneurs to pursue a range of reform measures that were otherwise unlikely to have been implemented. Adopting a 'never waste a crisis' approach, DPER was successful in introducing a wide range of reform measures that left no part of the public service unaffected. Many of these reforms, including shared services, performance budgeting and greater mobility of personnel across the public service, had been floated by the OECD's (2008) pre-crisis report. However other reforms, including the Civil Service Renewal Plan (and subsequent Civil Service Accountability Board) and open government initiatives, emerged uniquely from its work. The fact DPER was maintained by the minority government elected in 2016, when it could feasibly have been absorbed into the Department of Finance, is a testament to the position it created for itself over the 2011-16 period.

A multiple streams approach to the Irish public service reform efforts over the post-crisis period helps to explain how, in response to a perceived problem of an underperforming public service system, a wide-ranging set of reform initiatives were pursued. And though the outcome of each individual reform is beyond the scope of this paper, the 2011-16 period became one of unprecedented change for the Irish public service. The window of opportunity presented by the crisis was exploited by policy entrepreneurs from the political and administrative domains to implement major reform efforts in parallel.

The amalgamation of industrial relations with public expenditure within DPER provided a potent force for implementing these reform measures. And although the Croke Park Agreement was in place prior to the department's creation, the successor Haddington Road 
Agreement was a vital 'enabler' of major reform measures, including harmonisation of terms and conditions of employment, which provided for productivity increases. The Lansdowne Road Agreement set in motion the unwinding of crisis-era cuts, but by the end of the coalition's term of office, and in the context of economic improvements, pressure mounted for an acceleration of the process.

In terms of public expenditure, it remains to be seen if the reforms have collectively and completely arrested the problematic 'boom and bust' approach to public spending, and political pressures to spend over budget limits remain strong. Despite a large underlying debt arising from the Irish state guarantee of bank liabilities, improved economic realities in 2015 and 2016 also resulted in pressure for greater public spending and an end to 'austerity' measures. Thus, the pre-crisis pattern of focusing on short-term spending has not completely dissipated and the weight of influence exerted by new bodies such as the IFAC and the IGEES remains uncertain.

\section{References}

Bideleux, R. (2011). Contrasting responses to the international economic crisis of 2008-2010 in the 11 CIS countries and in the 10 post-communist EU member countries. Journal of Communist Studies and Transition Politics, 27 (3-4), 338-63.

Boyle, R. (2014). Public sector reform in Ireland: Views and experiences from senior executives [State of the Public Service Series, Report no. 13]. Dublin: Institute of Public Administration.

Cairney, P. (2012) Understanding public policy: Theories and issues. Basingstoke: Palgrave.

Coen, D., \& Roberts, A. (2012). A new age of uncertainty. Governance, 25 (1), 5-9.

Department of Finance. (2011). Reforming Ireland's budgetary framework: A discussion document. Retrieved from http://www.finance.gov.ie/sites/ default/files/budgetref.pdf [13 April 2017].

Department of Public Expenditure and Reform. (2011). Public service reform plan. Dublin: Department of Public Expenditure and Reform.

Department of Public Expenditure and Reform. (2014). Public service reform plan 2014-16. Dublin: Department of Public Expenditure and Reform.

Department of the Taoiseach. (2008). Transforming public services. Dublin: Department of the Taoiseach.

Dommett, K., Hardiman, N., \& MacCarthaigh, M. (2016). Reforming the Westminster model of agency governance: Britain and Ireland after the crisis. Governance, 29 (4), 535-52. 
Donovan, D., \& Murphy, A. E. (2013). The fall of the Celtic tiger: Ireland and the euro debt crisis. Oxford: Oxford University Press.

Downes, R., Kennedy, F., \& Nic Gearailt, M. (2013). Ireland Stat Government performance measurement. Administration, 60 (3), 189-200.

European Commission. (2013). Fiscal frameworks in the European Union: Commission services country factsheets for the autumn 2013 peer review. Brussels: European Commission.

Government of Ireland. (2010). National recovery plan 2011-2014. Dublin: The Stationery Office.

Government of Ireland. (2011). Programme for government. Dublin: Department of the Taoiseach.

Hardiman, N., \& MacCarthaigh, M. (2011) The un-politics of new public management in Ireland. In J.-M. Eymeri-Douzans \& J. Pierre (Eds), Administrative reforms and democratic governance (pp. 55-67). London: Routledge.

Hardiman, N., \& MacCarthaigh, M. (2016). State retrenchment and administrative reform in Ireland: Probing comparative policy paradigms. Journal of Comparative Policy Analysis. Advance online publication. doi: 10.1080/13876988.2015.1103432

Hardiman, N., MacCarthaigh, M., \& Scott, C. (2014). The Irish State Administration Database. Retrieved from www.isad.ie [28 December 2016].

Herweg, N., Hu, C., \& Zohlnhöfer, R. (2015). Straightening the three streams: Theorising extensions of the multiple streams framework. European Journal of Political Research, 54, 435-49.

John, P. (2012). Analyzing public policy. Oxford: Routledge.

Kickert, W. (2012). State responses to the fiscal crisis in Britain, Germany and the Netherlands. Public Management Review, 14 (3), 299-309.

Kingdon, J. W. (1995). Agendas, alternatives and public policies (2nd ed.). London: Longman.

Levine C. H. (1979). More on cutback management: Hard questions for hard times. Public Administration Review, 39 (2), 179-83.

Lodge, M., \& Hood, C. (2012). Into an age of multiple austerities? Public management and public service bargains across OECD countries. Governance, 25 (1), 79-101.

MacCarthaigh, M. (2014a). Agency termination in Ireland: Culls and bonfires, or life after death? Public Administration, 92 (4), 1,017-37.

MacCarthaigh, M. (2014b). Shared services in Ireland. In P. Laegreid, K. Sarapuu, L. H. Rykkja \& T. Randma-Liiv, Organizing for coordination in the public sector: Practices and lessons from 12 European countries (pp. 54-65). Basingstoke: Palgrave Macmillan.

Nyberg, P. (2011). Commission of Investigation into the Banking Sector in Ireland. Retrieved from http://www.bankinginquiry.gov.ie/ [13 April 2017].

OECD. (2008). Ireland: Towards an integrated public service. Paris: OECD.

Peters, B. G. (2011). Governance responses to the fiscal crisis - comparative perspectives. Public Money \& Management, 31 (1), 75-80. 
Peters, B. G., Pierre, J., \& Randma-Liiv, T. (2011, March). Economic crisis, public administration and governance. Do new problems require new solutions? Public Organization Review, 13-28.

Pollitt, C. (2010). Cuts and reforms. Public services as we move into a new era. Society and Economy, 32 (1), 17-31.

Regling, K., \& Watson, M. (2010). A preliminary report on the sources of Ireland's banking crisis. Retrieved from http://www.bankinginquiry.gov.ie/ Preliminary\%20Report\%20into\%20Ireland's\%20Banking\%20Crisis\%203 1\%20May\%202010.pdf [13 April 2017].

Shannon, L. (2016). Local and regional bodies in Ireland 2012-16 [Local Government Research Series, Report no. 12]. Dublin: Institute of Public Administration.

Thynne, I. (2011). Symposium introduction. The global financial crisis, governance and institutional dynamics. Public Organization Review, 11, $1-12$.

Whelan, K. (2014). Ireland's economic crisis: The good, the bad, and the ugly. Journal of Macroeconomics, 39 (B), 424-40.

Wright, R. (2010). Strengthening the capacity of the Department of Finance [Report of the Independent Review Panel]. Dublin: Department of Finance.

Zahariadis, N. (2016). Delphic oracles: Ambiguity, institutions, and multiple streams. Policy Sciences, 49 (3), 3-12. 